Veterinary Serum and Vaccine Research Institute, Abbassia, Cairo,

\title{
LOCAL IMMUNE RESPONSE AT RESPIRATORY TRACT OF CALVES VACCINATED WITH PASTEURELLA MULTOCIDA VACCINES
}

(With 4 Tables and 4 Figures)

By
A.M. DAOUD; HALA A.FADL; H. G.EL-DIN; MERVAT A.ELKOFY and S.M. ABOUL SAOUD

(Received at 26/12/2004)

\section{الاستجابة المناعية الموضعية في القناة التنفية للعجول الصغيرة المحصنة بلقاح التسمم الاموي \\ أحدد محمود داوود ، هالة أحمد فضل ، حامد بيوسف جمال الدين

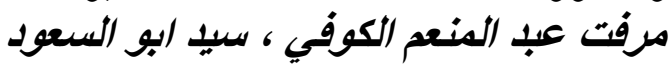

تم في هذه الدر اسـة بحث مدي فاعلية تحصين العجول عن طريق الأنف بلق بلقاح الباستريلا

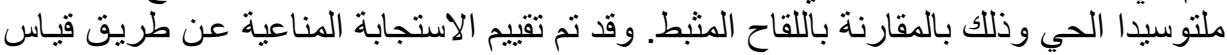

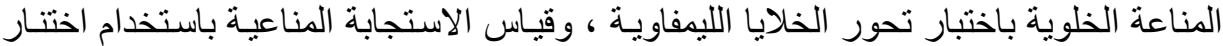

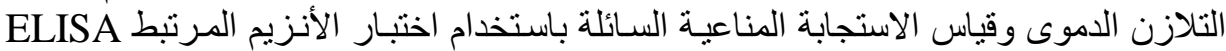

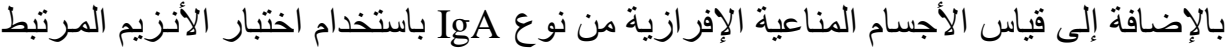

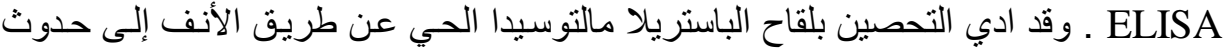

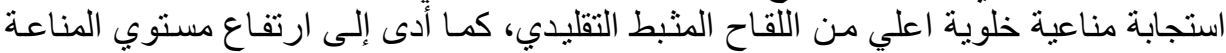

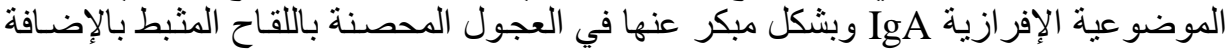
إلى المناعة السائلة من نوع الإنة

\section{SUMMARY}

In this study we investigate the effectiveness of intranasal vaccination of calves with live streptomycin-dependent mutant of P.multocida type B vaccine in comparison with inactivated one. Live P.multocida vaccine gave higher mitogenic response of the peripheral blood lymphocytes as measured by lymphocyte blastogenesis assay than inactivated one allover the period of the experiment. The haemagglutinating antibodies as measured by Passive haemagglutination test (HA) and the IgG as measured by ELISA rose from one day to reach the peak at 15 days, and then decline till 12 weeks post vaccination for live vaccine. However for 
inactivated vaccine it reached the peak at 8 weeks and then decline till 12 week post vaccination. Calves with live P.multocida vaccine gave higher and earlier secretory $\operatorname{Ig} \mathrm{A}$ in nasal secretions than inactivated one. In conclusion, the intranasal administration of live streptomycindependent serotype of P.multocida mutant vaccine was efficient and induced local cellular immune response, IgA antibodies and systemic $\mathrm{IgG}$ antibodies.

Key words: Respiratory tract, calves, Pasteurella multocida, vaccination.

\section{INTRODUCTION}

The protective immune response to a vaccine may be due to the presence of circulating antibody (humoral immunity), the actions of sensitized T-lymphocytes (cell-mediated immunity), the presence of secretory IgA on mucosal surfaces (mucosal immunity), and or a combination of these factors (Mestecky 1987). The most infectious agents enter via mucosal surfaces, thus, immunity at these sites would prevent initiation of infection (Babiuk et al, 1995). Since colonization of the organism on the respiratory mucosa seems to be a prerequisite for infection, antibodies in respiratory secretion may prevent or suppress the colonization of bacteria, and vaccinal immunity may be mediated by secretory antibodies. Secretory IgA is important in protecting against bacterial and viral diseases where the organism must attach to epithelial surfaces in order to produce disease (Roth, 1993). Gilmour et al, 1990, reported that locally produced humoral components, such as secretory IgA may played an active role in enhancing antibacterial defense of the lung and showed that exposure of the respiratory tract induces local and systemic immunity and hastens the elimination of inhaled bacteria in subsequent exposures. Stites et al., (1994) believed that IgA is the major immunoglobulin in nasal secretions. However, Brennan et al., (1998), found that $\operatorname{IgG}$ titers were higher than $\operatorname{IgA}$ titers in nasal secretions. Thus, the stimulation of secretory immune responses, which included mucosal IgA and IgG, the predominant antibodies in mucosal secretions are considered to be crucial to vaccine development (Outlaw et al 1990). The nasal route for vaccination offers some important opportunities, especially for the prophylaxis of respiratory diseases (Babiuk, 1999). Live attenuated vaccines have the advantage as a natural route of entry into the host. Aboul Saoud (1990) had previously developed a live streptomycin-dependent mutant of P.multocida type B, using N-methyl- 
$\mathrm{N}$-nitro-N-nitrosoguandine that has been shown to be highly immunogenic in mice, rabbits and calves. This vaccinal strain offered protection in calves against challenge with the homologous virulent P.multocida. However, little is known about the efficacy of intranasal administration of some antigens in inducing protective mucosal immunity to P. multocida in calves. So the aim of this study was to investigate the effectiveness of intranasal vaccination of calves with live streptomycin-dependent mutant of P.multocida type B vaccine in comparison with inactivated one through evaluation of the cell mediated immune response using lympholcyte blastogeneesis assay, humoral and secretory IgA against P.multocida using passive HA and (ELISA).

\section{MATERIALS and METHODS}

\subsection{Vaccines:}

3.1.1. Live vaccine a live streptomycin-dependent mutant of P.multocida type B, developed previously by Aboul Saoud (1990) using N-methyl-N-nitro-N-nitrosoguandine was obtained from

Dr. Aboul Saoud, Head of Aerobic Bacterial Vaccine Department, Veterinary Serum and Vaccine Research Institute, Abbassia, Cairo.

3.1.2. Dead vaccine: P.multocida strain (type B:6) a locally isolated strain from field cases of cattle with HS in Egypt (Geneidy and ElAffandy, 1963). Culture of P.multocida was prepared and standardized for vaccine production according to the method of Aboul Saoud et al., (2004).

Sterility tests were done by culturing the vaccines onto fluid thioglycolate, soya bean casein digest and Sabouroud's to check absence of bacteria before use. Also, safety tests were carried out for prepared vaccines by inoculation of a group of 10 healthy mice with $0.2 \mathrm{ml}$ subcutaneously (double vaccinal dose) and observed for 7 days for any untoward effect as the procedure described in De Alwis, 1989).

3.2. Calves: Seven normal healthy Holstein-Friesian calves, six month age were used. These calves were tested to be free from nasal and systemic P.multocida antibodies. Calves were allotted to three groups: Group (1) contains 3 calves, they were vaccinated intranasally with $2 \mathrm{ml}$ of a live streptomycin-dependent mutant of P.multocida vaccine (contain $10^{9}$ CFU) (Frank et al., 1987).Group (2) another 3 calves were vaccinated intramuscularly with $2 \mathrm{ml}$ of oil adjuvants vaccine (contain $10^{9} \mathrm{CFU}$ ) (Kucera et al., 1981). The third group (one calf) was left as non vaccinated control. 


\subsection{Samples:}

3.3.1. Blood samples: Blood was collected for estimation of lymphocyte transformation and serum separation before vaccination \& at 1, 2, 4, 7, $10,15,21,30,45,60,75,90$ days post-vaccination. Sera were collected and stored at $-20^{\circ} \mathrm{C}$ until assayed for serological assays for antibodies.

3.3.2. Nasal secretions: Nasal secretion samples were also collected as described by Brennan et al., (1998) at the same time intervals of blood sampling was subjected for detection of IgG \& IgA secretory antiPasteurella multocida antibodies.

3.4. Evaluation of cellular immunity: The mitogenic response of lymphocytes was determined by the delta of optical density (optical density) using phytohaemagglutinin as a $\mathrm{T}$ cell mitogen and 6- [3-(4,5Dimethyl thiazol-2-YL) 2,5-diphenyl Tetrazolium Bromide] (MTT). This test was carried according to Momann (1983). Peripheral blood lymphocyte was isolated from heparinized blood samples collected from jugular vein of calves $(2 \mathrm{ml})$. The samples were overlaid carefully with equal amounts of ficol (Flow Laboratories, UK) centrifuged at $2400 \mathrm{rpm}$ for 30 minute. The mononuclear leukocytes washed three times in HBSS. The viable lymphocytes were counted according to (Mayer et al., 1974) and a concentration of $5 \times 10^{6}$ cells were suspended in $1 \mathrm{ml}$ RPMI medium supplemented by $15 \%$ fetal calf serum (GIBCO). Tissue culture plates were used where 3 wells containing suspended lymphocytes only, 3 wells containing suspended lymphocytes and phytohemagglutinin solution and five wells containing growth medium only as control. The plates were incubated 48 hours at $37^{\circ} \mathrm{C}$ then $10 \mu$ MTT (Sigma)/well were added. Plates were incubated for 4 hours then $50 \mu$ /well SDS was added then incubated over night at $37^{\circ} \mathrm{C}$ and read at $750 \mathrm{~nm}$ wave length.

3.5. Evaluation of humoral immune response: This was estimated by passive HA test and (ELISA):

3.5.1. Passive haemagglutination test: Was carried out for measuring P.multocida antibodies according to Carter and Rappy (1962) in microtiter plates for measuring the passive haemagglutination antibodies by using formalized RBCs.

3.5.2. Enzyme linked immunosorbent assay (ELISA): For titration of antibody to P.multocida in serum of calves according to Marshall et al (1981) and performed in flat-bottom micro-titration plates (TPP, Switzerland). Preparation of ELISA antigen from mutant P.multocida, diluted with carbonate bicarbonate buffer $\mathrm{pH}$ 9.6. To the coated plates, $100 \mu \mathrm{l}$ of tested serum, each serum sample was diluted 1:500 (best 
dilution titer) including the control positive (was obtained from Dr. Aboul Saoud) and negative sera (Non vaccinated non infected calves) as well as the blank control (no serum, no conjugate and no substrate) and incubation at $37^{0} \mathrm{C}$ for one hour. Then $100 \mu \mathrm{l}$ of diluted conjugate (horseradish peroxidase sheep anti-bovine IgG, Serotec Company, UK) 1:12,000 (best dilution titer) were added to all wells. $100 \mu \mathrm{l}$ of substrate (OPD Sigma) was added for 15 minutes at $37^{\circ} \mathrm{C}$. The reaction was stopped by adding $50 \mu \mathrm{l} /$ well of $2 \mathrm{M}$. of sulphoric acid and absorbance (OD) values were read by using an ELISA reader at a wave length of $490 \mathrm{~nm}$. The transformation of absorbance values into a single figure representing the antibody titer depends on using a positive serum predetermined end titer to calculate the titers of the test samples according to Williams (1987). All samples were calculated as according to the following formula:

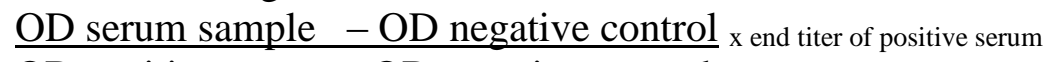
OD positive serum - OD negative control

3.6. Titration of IgA in nasal secretions: Enzyme linked immunosorbent assay (ELISA) were used for detection of $\operatorname{IgG} \& \operatorname{IgA}$ secretory anti-P.multocida antibodies according to Brennan et al., (1998). To the coated plates, $100 \mu \mathrm{l}$ of tested nasal secretions, each nasal secretions sample was diluted 1:50 (best dilution titer) and incubation at $37^{0} \mathrm{C}$ for one hour. Then $100 \mu \mathrm{l}$ of diluted conjugate (horseradish peroxidase sheep anti-bovine IgA, Serotec, Company, UK) 1:2,000 (best dilution titer) were added to all wells and 1:12,000 for $\mathrm{IgG}$ and completed as IgG.

\section{RESULTS}

The mitogenic response of the peripheral blood lymphocytes of live vaccine were elevated from one day to reach the peak at 7 days post vaccination and then decline till 4 weeks. The mitogenic response of the peripheral blood lymphocytes of inactivated vaccine were elevated from one day to reach the peak at two weeks post vaccination and then decline till 4 weeks the end of observation period (table and figure 1).

As shown in table and figure 2, the haemagglutinating antibody after vaccination with live vaccine was rose from one day to reach the peak at 15 days post vaccination and then decline till 4 weeks. the end of observation period. For inactivated vaccine it rose from one day to reach the peak at 8 weeks post vaccination and then decline till 12 weeks the end of observation period. 
It can be shown from table and figure 3, that IgG in serum of calves after vaccination with live vaccine as measured by ELISA were rose from one day to reach its peak at 3 weeks post vaccination and then decline till 12 weeks. After vaccination with inactivated vaccine $\operatorname{IgG}$ was rose from one day to reach the peak at 8 weeks post vaccination and then decline till 12 weeks.

It can be seen from (table and figure 4) that IgA in nasal secretions of calves after vaccination with live vaccine as measured by ELISA was rose from one day to reach the peak at 3 weeks post vaccination and then decline till 12 weeks. $\operatorname{IgA}$ in nasal secretions of calves after vaccination with dead vaccine was rose from one day to reach the peak at 8 weeks post vaccination and then decline till 12 weeks.

The haemagglutinating antibody did not rise in nasal secretions of calves after vaccination with live and dead vaccines as measured by passive haemagglutination test. Also, there was a tracing of antibodies of Anti-P.multocida IgG in nasal secretions of calves after vaccination with live vaccine and dead vaccines as measured by ELISA.

\section{DISCUSSION}

Induction of mucosal immunity begins with the uptake of antigen by membranous (M) cells (specialized epithelial cells) on the mucosal surface. These cells either process and present antigen to underlying $\mathrm{T}$ cells or B cells themselves or transport antigen to parenchymal macrophages, dendritic and $\mathrm{B}$ cells. Once interactin of the antigen presenting cell (APC) with $\mathrm{T}$ and $\mathrm{B}$ lymphocytes has occurred, an immune response or mucosal tolerance may result. Immune responses generally involve antibody production with $\operatorname{IgA}$ the predominant antibody isotype. Antigen sensitized immune cells are then circulated to other systemic and mucosal sites for expansion of effector mechanisms (Mestecky 1987).

In the present study we investigated the effectiveness of intranasal vaccination with live streptomycin-dependent mutant of P.multocida type B vaccine in comparison with inactivated one.

The mitogenic response of the peripheral blood lymphocytes was estimated by phytohaemaggulutinin in the trial to evaluate the cellular immune response of calves vaccinated with P.multocida vaccines. The results shown in (Table and Figure 1) indicated that live P.multocida vaccine gave higher immune response than inactivated one allover the 
period of the test. These results were coincide with that of El-Kofy (1997) who proved that vaccination of ducks by live duck virus hepatitis gave higher $\triangle \mathrm{OD}$ than that of inactivated one. Also, the same results were detected by Maheswaran and theis (1979) who reported that lymphocytes from cattle immunized with various strains of P.multocida showed higher stimulation indices when incubated with homologous antigen, which suggested an involvement of cell mediated immunity. Moreover, Local CMI response to IBR virus were greater in cattle vaccinated intranasally than in cattle vaccinated intramuscularly (Gerber et al., 1978).

As shown in table and figure $2 \& 3$, the haemagglutinating antibodies as measured by Passive haemagglutination test and $\mathrm{IgG}$ as measured by ELISA after vaccination with live vaccine were elevated from one day to reach the peak at 15 days post vaccination and then decline till 12 weeks the end of observation period. The haemagglutinating antibody and $\operatorname{IgG}$ after vaccination with inactivated vaccine was rose from one day to reach the peak at 8 weeks post vaccination and then decline till 12 weeks.

Secretory $\operatorname{IgA}$ is important in protecting against bacterial and viral diseases where the organism must attach to epithelial surfaces in order to produce disease and against diseases induced by toxins produced at mucosal surfaces.

The findings in (Table and Figure 4) indicated that intranasal vaccination of calves with live P.multocida vaccine induced local IgA antibodies and gave higher and earlier P.multocida antibody (IgA) than inactivated one. These results were coincide with that of Brennan et al, (1998) who found that intranasal administration of P.haemolytica 1:A may be a better method for stimulating protective immune responses in the upper portion of the respiratory tract than lung administration. As such, local secretory antibodies (specific IgA) are produced due to intranasal vaccination with live P.multocida vaccine, which may be an advantage in preventing natural infection of haemorrhagic septicemia. Also, Tomoda et al. (1995) found that the IgA antibody was negligibly detected in the nasal wash specimens before vaccination, and was induced by vaccination.

Gilmour et al, (1990) reported that locally produced humoral components, such as secretory $\mathrm{IgA}$ and mucosal $\mathrm{IgG}$, may have played an active role in the enhanced antibacterial defense of the lung and showed that exposure of the respiratory tract induces local and systemic 
immunity and hastens the elimination of inhaled bacteria in subsequent exposures.

The haemagglutinating antibody did not rise in nasal secretions of calves after vaccination with live and dead vaccines as measured by passive haemagglutination test. Also, there was a trace amount of antibodies of Anti-P.multocida IgG in nasal secretions of calves after vaccination with live vaccine and dead vaccines as measured by ELISA. In contrast to the results described previously by Brennan et al., (1998), who found that $\operatorname{IgG}$ titers were higher than IgA titers in nasal secretions, in this work $\operatorname{IgG}$ was present in trace amount in nasal secretions and this may be due to the ratios of $\operatorname{IgG\operatorname {IgA}}$ in lower respiratory tract secretion which should be greater than that in upper respiratory tract secretions (Quinn et al, 2002). However, Stites et al, (1994) believed that IgA is the major immunoglobulin in nasal secretions.

In addition, control calves remained seronegative for P.multocida antibodies till the end of experiment.

The above findings indicated that the intranasal administration of live streptomycin-dependent serotype of P.multocida mutant vaccine was efficient and induced cellular immune response, local $\operatorname{IgA}$ antibodies and systemic IgG antibodies. These results were coinciding that of Ellis, (1999) who reported that live vaccines usually elicit both humoral immunity as well as cellular immunity. Also, Gerber et al, (1978) whom found that intranasal or intramuscular vaccination with Infectious bovine Rhino-tracheitis virus (IBR) stimulated local and systemic antibody but the local immune responses to IBR in IM vaccinated calves were not as strong as in $\mathrm{I} / \mathrm{N}$ vaccinated calves.

In conclusion, for prevention and recovery from P.multocida infection, intranasal vaccination is the best route as it induced cellular immune response, local IgA antibodies and systemic IgG antibodies.

\section{REFERENCES}

Aboul Saoud, S.M. (1990): Immunological studies on P.multocida vaccines. A thesis for PhD., Faculty of Vet. Med., Cairo University, Egypt.

Aboul Saoud, S.M.; Diab, R.A.; Manal S. Mahmoud and Daoud, A.M. (2004): Trial for preparing a vaccine giving earlier immune response against haemorrhagic septicaemia in calves. Vet. Med. J., Giza, 52, 3, 369-378.

Babiuk, L.A. (1999): Broadening the approaches to developing more effective vaccines. Vaccine 17, 1587-1595. 
Babiuk, L.A.; Morsy, M.; Campos, M. and Harland, R. (1995): Viralbacterial synergistic interactions/pathogenesis in cattle. Proceedings of the Third International Conference on Haemophilus, Actinobacillus and Pasteurella, Edinburgh, Scotland, UK, 39-50.

Bowland, S.L. and Shewen, P.E. (2000): Bovine respiratory disease: Commercial vaccines currently available in Canada. Can.Vet. J., 41, 33-48.

Brennan, R.E.; Corstvet, R.E. and Paulson, D.B. (1998): Antibody responses to Pasteurella haemolytica 1:A and three of its outer membrane proteins in serum, nasal secretions, and bronchoalveolar lavage fluid from calves. Am. J. Vet. Res., 59, 6, 727-732.

Carter, G.R. and Rappy, D.E. (1962): Formalinized erythrocytes in the haemagglutination test for typing Pasteurella multocida. Brit.Vet.J., 118, 289-292.

De Alwis, M.C.L. (1989): Haemorrhagic septicaemia, L.Blajan O.I.E. Manual of Recommended Diagnostic Techniques and Requirements for biological products, Paris, VI, B108-1/8-8/8.

El-Kofy A. Mervat (1997): Studies on Preparation and evaluation of vaccine from Local field strain of duck virus hepatitis. Ph.D.Sc.Thesis, poltry and Rabbit diseases. Fac. Vet. Med., Cairo. Univ.

Ellis, R.W. (1999): New technologies for making vaccines. 17, 15961604.

Frank, G.H.; Briggs, R.E. and Gillette, K.G. (1987): Pasteurella haemolytica serotype 1 colonization of the nasal passages of virus-infected calves. Am. J. Vet. Res., 48, 12, 1674-1677.

Geneidy, A.A. and El-Affandy, A.M. (1963): A study of Pasteurella strains isolated from field cases during the last eight years. Egypt $4^{\text {th }}$ Arab Ann.Vet. Cong., Cairo.

Gerber, J.D.; Marron, A.E. and Kucera, C.J. (1978): Local and systemic cellular and antibody immune responses of cattle to Infectious Bovine Rhinotracheitis virus vaccines administered intranasally or intramuscularly. Am. J. Vet. Res. 39, 5, 753-760.

Gilmour, M.I.; Wathes, C.M. and Taylor, F.G.R. (1990): The airborne survival of Pasteurella haemolytica and its deposition in and clearance from the mouse lung. Veterinary Microbiology, 21, 363. 
Kucera, C.J.; Wong, J.C.S.; and Eis, R.L. (1981): Develpment of a chemically altered Pasteurella multocida vaccinal strain. Am. J. Vet. Res. 42, 8, 1389-1394.

Maheswaran, S.K. and Theis, E.S. (1979): Pasteurella multocida antigen induced in vitro lymphocytes immunostimulation using whole blood from cattle and turkey. Res.Vet. Sci., 26, 25-31.

Marshall, M.S.; Robison, R.A. and Jensen, M.M. (1981): Use of an Enzyme Linked Immunosorbent Assay to measure antibody responses in turkeys against P.multocida. Avian Dis. 25, 4, $964-$ 971.

Mayer, S.P.; Ritts, G.D. and Johson, D.R. (1974): Phytohemagglutination induced leukocytes blastogenesis in normal and avian leucosis virus infection in chicken cells. Immunol., 27, 140-146.

Mestecky, J. (1987): The common mucosal immune system and current strategies for induction of immune responses in external secretions. J.Clin.Immunol. 7, 265-276.

Momann, T. (1983): Rapid calorimetric assay for cellular growth and cytotoxicity assays. J. Immunol. Meth , 65,55.

Outlaw, M.C. and Dimmock, N.J. (1990): Mechanism of neutralization of influenza virus on mouse tracheal epithelial cells by mouse monoclonal polymeric IgA and polyclonal IgM directed against the viral haemagglutinin. J. Gen. Virol. 71, 69-76.

Quinn, P.J.; Markey, B.K.; Carter, M.E.; Donnelly, W.J.C. and Leonard, F.C. (2002): Veterinary Microbiology and Microbial disease. pp. 461-464.

Roth, J.A. (1993): Characterization of protective antigens and the protective immune response. Veterinary Microbiology, 37, 193199.

Stites, D.P; Terr, A.I.; and Parslow, T.G. (1994): Basic and clinical immunology. $8^{\text {th }}$ ed. Norwalk, Conn: Appleton \& Lange, 541551.

Tomoda, T.; Morita, H.; Kurashige, T. and Maassab, H.F. (1995): Prevention of influenza by the intranasal administration of coldrecombinant, live-attenuated influenza virus vaccine: importance of interferon- $\sqrt{ }$ production and local IgA response. Vaccine, 13, 2, 185-190.

Williams, $R$. (1987): A single dilution Enzyme Linked Immunosorbant Assay for the quantitative detection of antibodies to African Horse Sickness virus. Onderstepoort j. Vet. Res., 54, 67-70. 
Table 1: Evaluation of cell mediated immune response of cattle vaccinated with P.multocida vaccines, using lymphocyte blastogenesis.

\begin{tabular}{|c|c|c|c|c|c|c|c|c|c|c|}
\hline & & & $\begin{array}{c}1 \\
\text { day }\end{array}$ & $\begin{array}{c}2 \\
\text { days }\end{array}$ & $\begin{array}{c}4 \\
\text { days }\end{array}$ & $\begin{array}{c}7 \\
\text { days }\end{array}$ & $\begin{array}{c}10 \\
\text { days }\end{array}$ & 2 weeks & 3 weeks & $\begin{array}{c}4 \\
\text { weeks }\end{array}$ \\
\hline \multirow{4}{*}{$\begin{array}{c}\text { Live } \\
\text { vaccine }\end{array}$} & \multirow{4}{*}{$\Delta \mathrm{OD}$} & 1 & 0.088 & 0.108 & 0.190 & 0.233 & 0.221 & 0.210 & 0.164 & 0.125 \\
\hline & & 2 & 0.086 & 0.117 & 0.195 & 0.229 & 0.219 & 0.200 & 0.126 & 0.128 \\
\hline & & 3 & 0.090 & 0.119 & 0.198 & 0.230 & 0.214 & 0.209 & 0.114 & 0.143 \\
\hline & & Mean & 0.088 & 0.115 & 0.194 & 0.231 & 0.218 & 0.206 & 0.135 & 0.132 \\
\hline \multirow{4}{*}{$\begin{array}{c}\text { In- } \\
\text { activated } \\
\text { vaccine }\end{array}$} & \multirow{4}{*}{$\Delta \mathrm{OD}$} & 1 & 0.062 & 0.065 & 0.07 & 0.077 & 0.085 & 0.098 & 0.052 & 0.037 \\
\hline & & 2 & 0.060 & 0.063 & 0.068 & 0.065 & 0.090 & 0.094 & 0.050 & 0.033 \\
\hline & & 3 & 0.068 & 0.067 & 0.071 & 0.073 & 0.093 & 0.096 & 0.043 & 0.034 \\
\hline & & Mean & 0.063 & 0.065 & 0.070 & 0.072 & 0.089 & 0.096 & 0.048 & 0.035 \\
\hline Control & $\Delta \mathrm{OD}$ & 1 & 0.004 & 0.010 & 0.004 & 0.011 & 0.017 & 0.021 & 0.025 & ND \\
\hline
\end{tabular}

* $\triangle \mathrm{OD}$ : Delta Optical Density Values.

** ND : Not detected.

Figure (1) Evaluation of cell mediated immune response of cattle vaccinated with $P$.multocida vaccines, using lymphocyte

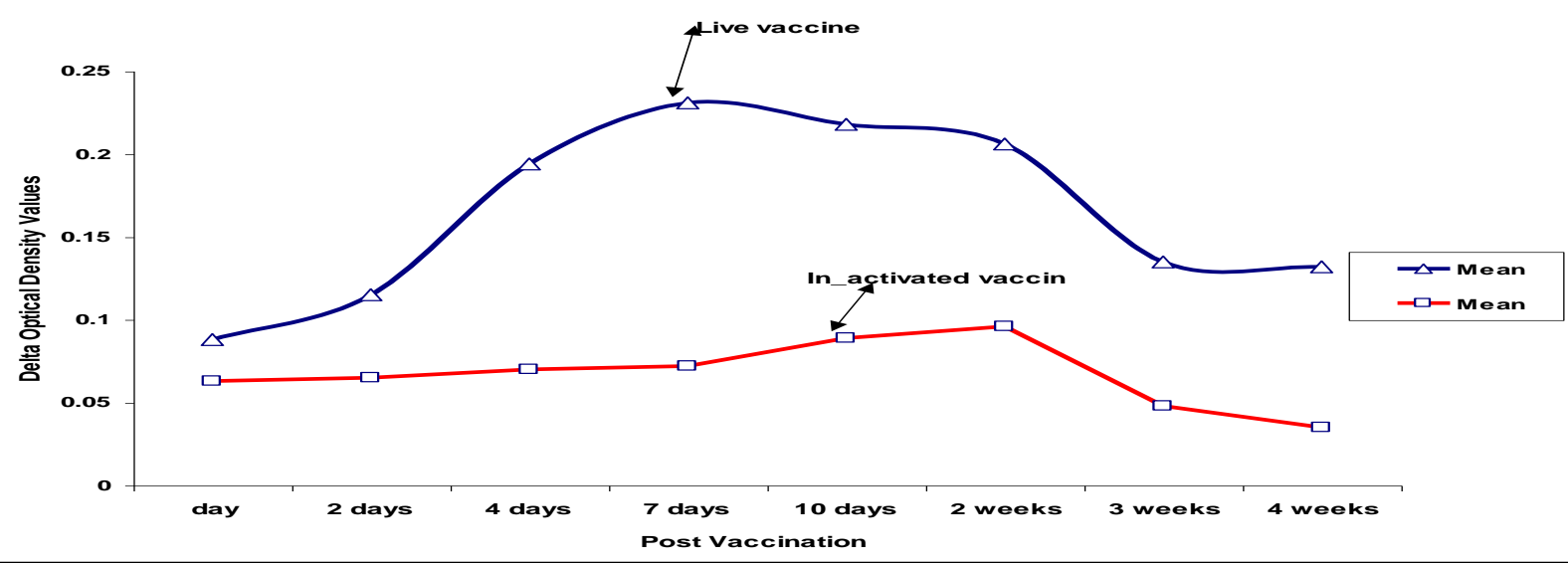

blastogenesis. 
Table (2) Haemagglutinating antibodies of P.multocida in serum of calves following vaccination with live and inactivated P.multocida vaccine as measured by Passive haemagglutination test.

\begin{tabular}{|c|c|c|c|c|c|c|c|}
\hline $\begin{array}{c}\text { Time post } \\
\text { vaccination }\end{array}$ & \multicolumn{5}{|c|}{ Live vaccine } & \multicolumn{3}{c}{ Inactivated va } \\
\hline & 1 & 2 & 3 & Mean & 4 & 5 & 6 \\
\hline One day & 16 & 16 & 16 & 16 & 8 & 8 & 1 \\
\hline Two days & 32 & 16 & 32 & 26.6 & 16 & 16 & $3:$ \\
\hline Four days & 64 & 32 & 32 & 42.6 & 32 & 16 & $3:$ \\
\hline Seven days & 64 & 64 & 64 & 64 & 32 & 32 & $3:$ \\
\hline Ten days & 128 & 128 & 128 & 128 & 64 & 64 & 6 \\
\hline Two weeks & 512 & 256 & 512 & 426.6 & 64 & 64 & 6 \\
\hline Three weeks & 256 & 128 & 512 & 298.6 & 128 & 64 & 12 \\
\hline Four weeks & 256 & 128 & 256 & 213.3 & 128 & 128 & 12 \\
\hline Six weeks & 128 & 128 & 128 & 128 & 256 & 128 & 12 \\
\hline Eight weeks & 128 & 128 & 128 & 128 & 512 & 512 & 51 \\
\hline Ten weeks & 128 & 128 & 128 & 128 & 512 & 512 & 25 \\
\hline Twelve weeks & 64 & 64 & 64 & 64 & 256 & 256 & 25 \\
\hline
\end{tabular}

Figure (2) Haemagglutinating antibodies of P.multocida in serum of calves following vaccination with live and inactivated $P$.multocida vaccine as measured by Passive haemagglutination test.

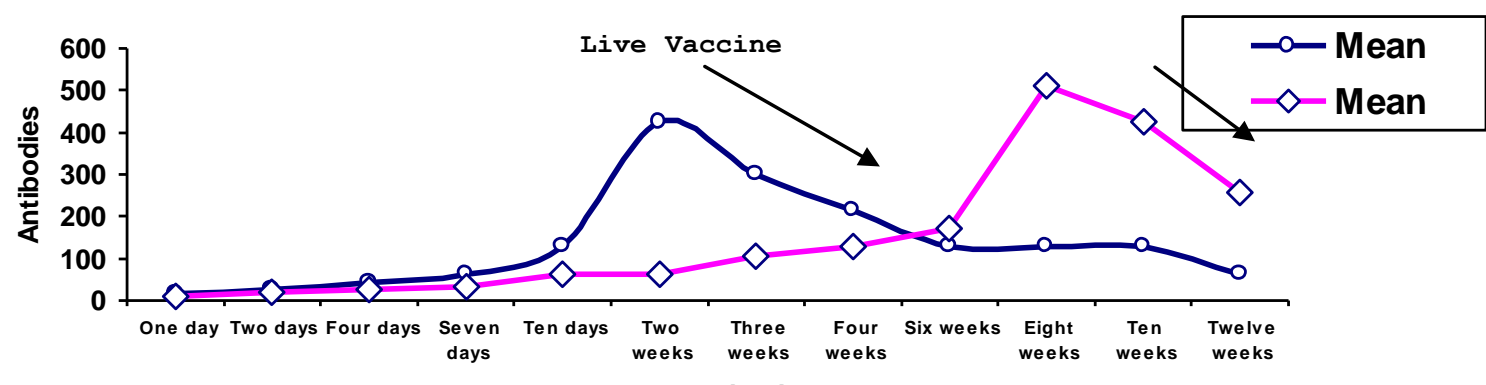

Post Vaccination 
Inactivated Vaccine

Table (3) Antibodies of P.multocida (IgG) in serum of calves following vaccination with live and inactivated P.multocida vaccine as measured by ELISA.

\begin{tabular}{|c|c|c|c|c|c|c|c|}
\hline $\begin{array}{c}\text { Time post } \\
\text { vaccination }\end{array}$ & \multicolumn{3}{|c|}{ Live vaccine } & \multicolumn{3}{c}{ Inactivated va } \\
\hline & 1 & 2 & 3 & Mean & 4 & 5 & 6 \\
\hline One day & 1110 & 552 & 471 & 711 & 593 & 491 & 57 \\
\hline Two days & 1637 & 1485 & 1075 & 1399 & 1130 & 1024 & 111 \\
\hline Four days & 2043 & 1805 & 1871 & 1906.3 & 1010 & 1357 & 140 \\
\hline Seven days & 2621 & 2662 & 2398 & 2560.3 & 1617 & 1626 & 159 \\
\hline Ten days & 3640 & 5299 & 4467 & 4468.6 & 1485 & 1637 & 180 \\
\hline Two weeks & 3975 & 4452 & 4274 & 4233.6 & 1551 & 1501 & 185 \\
\hline Three weeks & 6034 & 5126 & 5070 & 5410 & 1419 & 1490 & 197 \\
\hline Four weeks & 4492 & 4533 & 5309 & 4778 & 1992 & 1856 & 229 \\
\hline Six weeks & 4229 & 4143 & 4279 & 4217 & 5409 & 4997 & 318 \\
\hline Eight weeks & 3420 & 3042 & 3103 & 3188.3 & 4675 & 4716 & 547 \\
\hline Ten weeks & 2107 & 2598 & 2297 & 2334 & 3894 & 3768 & 342 \\
\hline Twelve weeks & 1296 & 1730 & 1092 & 1372.6 & 3879 & 3692 & 228 \\
\hline
\end{tabular}


Figure (3) Antibodies of P.multocida (IgG) in serum of calves following vaccination with live and inactivated $P$.multocida vaccine as measured by ELISA.

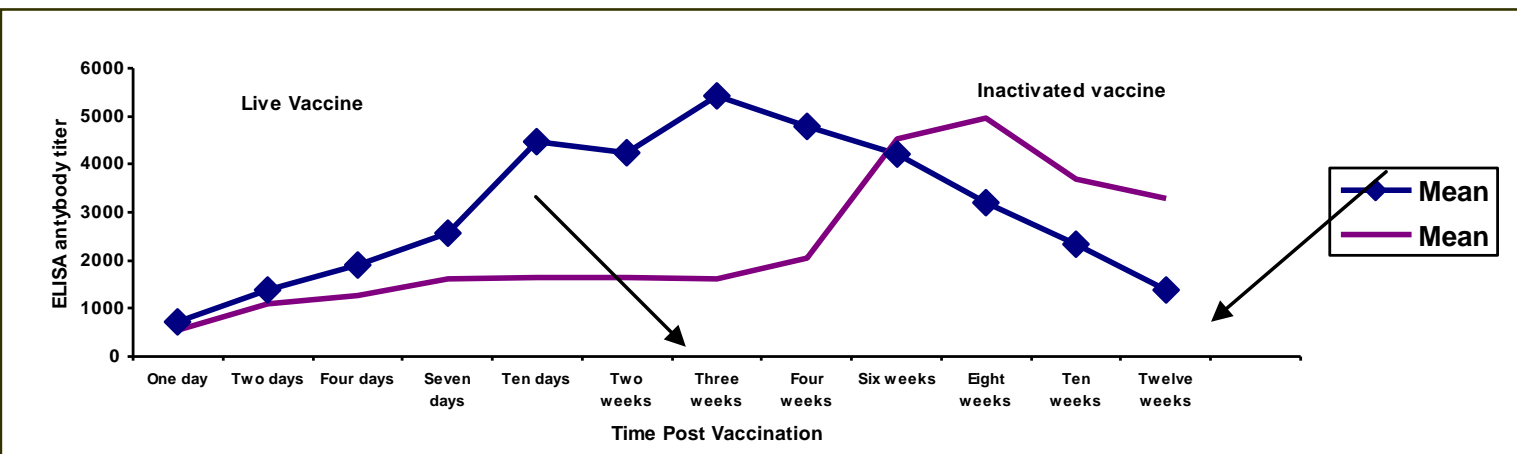

Table (4) IgA in nasal secretion of calves following vaccination with

live and inactivated $P$.multocida vaccine as measured by ELISA.

\begin{tabular}{|c|c|c|c|c|c|c|r}
\hline $\begin{array}{c}\text { Time post } \\
\text { vaccination }\end{array}$ & \multicolumn{3}{|c|}{ Live vaccine } & \multicolumn{3}{c}{ Inactivated va } \\
\hline & 1 & 2 & 3 & Mean & 4 & 5 & 6 \\
\hline One day & 316 & 451 & 780 & 515.6 & 633 & 516 & 45 \\
\hline Two days & 1513 & 1119 & 1396 & 1342.6 & 1100 & 1119 & 99 \\
\hline Four days & 2433 & 1570 & 1812 & 1938.3 & 1450 & 1434 & 139 \\
\hline Seven days & 4649 & 2398 & 3001 & 3349.3 & 1570 & 1674 & 157 \\
\hline Ten days & 4662 & 3448 & 3435 & 3848.3 & 1740 & 1825 & 169 \\
\hline
\end{tabular}




\begin{tabular}{|c|c|c|c|c|c|c|c}
\hline Two weeks & 5100 & 3959 & 4402 & 4487 & 1795 & 1964 & 182 \\
\hline Three weeks & 5109 & 6380 & 4259 & 5249.3 & 2403 & 2198 & 200 \\
\hline Four weeks & 3691 & 2710 & 1695 & 2698.6 & 2540 & 2285 & 229 \\
\hline Six weeks & 3257 & 2316 & 1292 & 2288.3 & 3990 & 4484 & 375 \\
\hline Eight weeks & 2528 & 1795 & 1158 & 1827 & 4482 & 5248 & 496 \\
\hline Ten weeks & 3335 & 1001 & 854 & 1730 & 2958 & 2697 & 248 \\
\hline Twelve weeks & 633 & 156 & 563 & 450.6 & 1460 & 459 & 150 \\
\hline
\end{tabular}

Figure (4) IgA in nasal secretion of calves following vaccination with $l i v e$ and inactivated $P$.multocida vaccine as measured by ELISA.

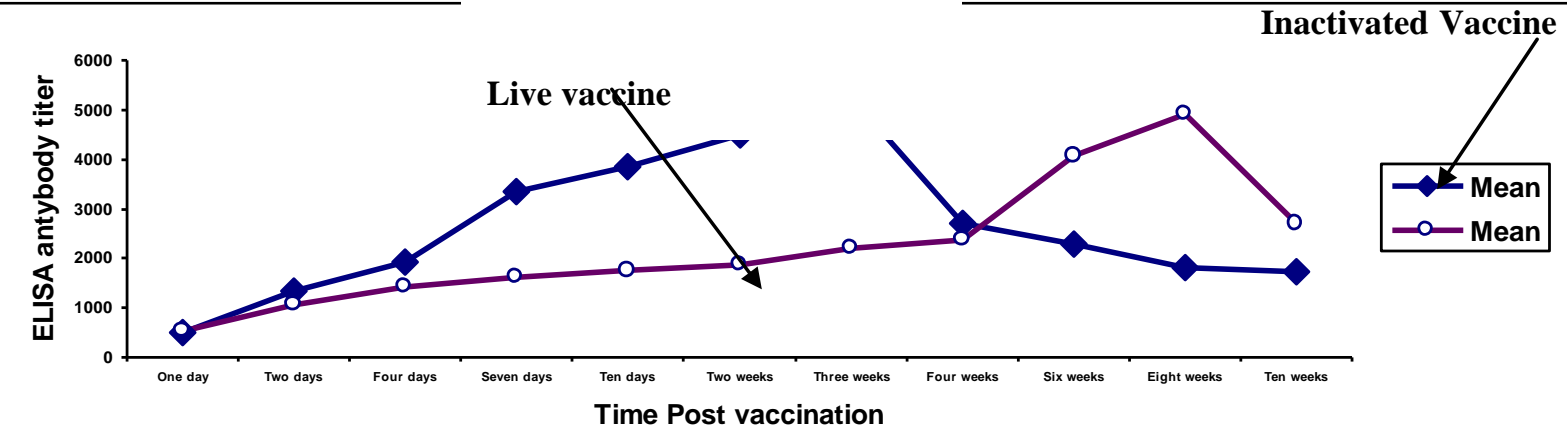


Assiut Vet. Med. J. Vol. 51 No. 104 January 2005

$$
\text { معهذ بحوث اللأمصال و اللقاحات البيطرية - العباسية }
$$


Table 1: Evaluation of cell mediated immune response of cattle vaccinated with P.multocida vaccines, using lymphocyte blastogenesis.

Figure 1: Evaluation of cell mediated immune response of cattle vaccinated with P.multocida vaccines, using lymphocyte

Table 2: Haemagglutinating antibodies of P.multocida in serum of calves following vaccination with live and inactivated P.multocida vaccine as measured by Passive haemagglutination test.

Figure 2: Haemagglutinating antibodies of P.multocida in serum of calves following vaccination with live and inactivated P.multocida vaccine as measured by Passive haemagglutination test.

Table 3: Antibodies of P.multocida (IgG) in serum of calves following vaccination with live and inactivated P.multocida vaccine as measured by ELISA.

Figure 3: Antibodies of P.multocida (IgG) in serum of calves following vaccination with live and inactivated P.multocida vaccine as measured by ELISA.

Table 4: IgA in nasal secretion of calves following vaccination with live and inactivated P.multocida vaccine as measured by ELISA.

Figure 4: IgA in nasal secretion of calves following vaccination with live and inactivated P.multocida vaccine as measured by ELISA.

* $\triangle \mathrm{OD}$ : Delta Optical Density Values.

** ND : Not detected. 